\title{
Crop Response to Soil Acidity Factors in Ultisols and Oxisols in Puerto Rico X1. Cassava ${ }^{1,2}$
}

\author{
Edmundo Rivera, Fernando Abruña and José Rodríguez ${ }^{3}$
}

\begin{abstract}
Cassava (Manihot esculenta Crantz), one of the major sources of carbohydrates throughout the tropics, was found to be very tolerant to high soil acidity in two Ultisols and one Oxisol. About $85 \%$ of maximum yields were obtained when Al saturation of the effective cation exchange capacity of the soil was around $60 \%$, but highest yields were attained at about $\mathrm{pH} 5.3$ with no exchangeable Al. Soil acidity factors did not affect the chemical composition of the cassava leaves, except for $\mathrm{Mn}$, which increased with decreasing $\mathrm{pH}$ of the Oxisol. Tolerance of cassava to soil acidity was also confirmed by the fact that yields of 12 commercial varieties were not affected by Al saturation levels varying from 0 to $60 \%$ in an Ultisol.
\end{abstract}

\section{INTRODUCTION}

Root crops are a major source of carbohydrates for millions throughout the tropics. Cassava (Manihot esculenta Crantz) is one of the most important root crops of the tropics in terms of both area and total production.

Despite its importance, little and often contradictory information is available on the response of cassava to liming. Sithioboosaya et al. (5) found no response by cassava to applications of $2 \mathrm{t}$ of limestone/ha in Thailand. Howler et al. (3), working with Carimagua soils in Colombia, found that only 20 of 134 varieties of cassava responded to liming; some responded to $2 \mathrm{t}$ of limestone/ha, and others to only $0.5 \mathrm{t} / \mathrm{ha}$. Also at Carimagua, Spain et al. (6) found that most of 138 cassava cultivars responded to limestone applications of up to $2 \mathrm{t} / \mathrm{ha}$. Some cultivars performed equally well at $0,0.5$ and $2 \mathrm{t}$ lime/ha, and some were adversely affected by the application of $6 \mathrm{t}$ limestone/ha. This adverse effect was apparently due to lime-induced $\mathrm{K}$ and minor element deficiencies. Edwards and Kang (2) found that in Nigeria cassava growing on very acid soils responded to applications of about $1.5 \mathrm{t}$ of calcitic limestone/ha.

The present studies were undertaken to determine the effect of soil acidity factors on yield and foliar composition of cassava growing on two Ultisols and one Oxisol.

${ }^{1}$ Manuscript submitted to Editorial Board January 25, 1984.

${ }^{2}$ This paper covers work carried out cooperatively between the Agricultural Research Service, USDA, and the Agricultural Experiment Station, College of Agricultural Sciences, Mayagüez Campus, University of Puerto Rico.

${ }^{3}$ Horticulturist and Soil Scientist, respectively, Agricultural Research Service, US; and Associate Agronomist, Agricultural Experiment Station, College of Agricultural Sciences, Mayagüez Campus, University of Puerto Rico. 


\section{MATERIALS AND METHODS}

Experiments were conducted on plots arranged in a randomized blocks design and differing in soil acidity because of differential applications of calcitic limestone over a period of years prior to these experiments.

The sites were on Corozal clay (clayey, mixed, isohyperthermic Aquic Tropudults), Corozal clay subsoil, and Coto sandy clay (clayey, kaolinitic, Tropeptic Haplorthox). There were 30 plots at each of the Corozal clay sites and 40 on the Coto sandy clay. Plots were 4 by $4 \mathrm{~m}$, surrounded by $15 \mathrm{~cm}$ deep ditches to prevent runoff from one plot into another.

All plots were planted August 1979 with stem sections of the Pana variety at $1 \times 1 \mathrm{~m}$. One and 5 months after planting, all plots received $500 \mathrm{~kg} / \mathrm{ha}$ of a 10-10-10 fertilizer containing $30 \mathrm{~kg} / \mathrm{t}$ of a minor element mixture containing $6 \% \mathrm{Mg}, 7.7 \% \mathrm{Mn}, 4.8 \% \mathrm{Cu}, 7 \% \mathrm{Fe}, 8 \% \mathrm{Zn}$ and $2.4 \%$ B. The plants were sprayed periodically for insect control. Yields of edible roots were determined 10 months after planting.

The third and fourth leaves of plants growing in the center of each plot were sampled 6 months after planting. They were washed with distilled water, dried at $70^{\circ} \mathrm{C}$, and analyzed by the Kjeldahl method for $\mathrm{N}$, colorimetrically for $\mathrm{P}$, by flame photometry for $\mathrm{K}$, by the Versenate method (1) for Ca and $\mathrm{Mg}$, and colorimetrically as $\mathrm{KMnO}_{4}$ for $\mathrm{Mn}$.

Ten soil samples were taken at 0 to 15 - $\mathrm{cm}$ depths in each plot about 4 months after planting, air dried, and passed through a 20-mesh sieve. Exchangeable $\mathrm{Ca}, \mathrm{Mg}, \mathrm{K}$ and $\mathrm{Mn}$ were extracted with neutral $1 \mathrm{~N} \mathrm{NH}_{3}$ OAc. Calcium and $\mathrm{Mg}$ were determined by the Versenate titration method (1), $\mathrm{K}$ by flame photometry and $\mathrm{Mn}$ colorimetrically as $\mathrm{MnO}_{4}$. Exchangeable $\mathrm{Al}$ was extracted with $1 \mathrm{~N} \mathrm{KCl}$ and determined by McLean's doubletitration method. Percent Al saturation of the soil was calculated, considering exchangeable $\mathrm{Ca}+\mathrm{Mg}+\mathrm{K}+\mathrm{Al}+\mathrm{H}$ as the effective cation exchange capacity (CEC) of the soil. Soil reaction was measured with a glass electrode $\mathrm{pH}$ meter using a 1:1.5 soil-water ratio.

An experiment was carried out on a Corozal clay soil to determine the relative tolerance to soil acidity of 12 cassava varieties. A split-plot design was used with soil acidity levels as the main plots and varieties as the subplots.

Main plots (soil acidity levels) were $16 \times 12 \mathrm{~m}$ surrounded by $15 \mathrm{~cm}$ deep ditches to prevent runoff from one plot into another. Subplots (varieties) were $4 \times 4 \mathrm{~m}$. All varieties were replicated four times within each of six soil acidity levels for a total of 288 plots.

To establish the desired range of soil acidity in the various plots, soil samples were taken in each and analyzed to determine the $\mathrm{CaCO}_{3}$ required to establish the desired level of acidity, varying from $\mathrm{pH} 4.0$ and $70 \% \mathrm{Al}$ saturation to $\mathrm{pH} 6.5$ and $0 \% \mathrm{Al}$ saturation. Six months later each 
plot was sampled by taking 10 borings at 0 to $15 \mathrm{~cm}$ depths. The samples were air dried and analyzed by the previously described methods. Plots were grouped in $15 \% \mathrm{Al}$ saturation levels with $0 \mathrm{Al}$ content as a separate rank.

In June 1980, 12 of the major commercial varieties were planted in plots which were fertilized and treated as previously described. The

TABLE 1.-Effect of soil acidity factors on yield and foliar composition of cassava grown on two Ultisols and one Oxisol. All values are means of at least four plots for Corozal soils and six for Coto soil

\begin{tabular}{|c|c|c|c|c|c|c|c|c|}
\hline \multicolumn{2}{|c|}{ Soil acidity factors } & \multirow{2}{*}{ Yields } & \multicolumn{6}{|c|}{ Leaf contents } \\
\hline $\mathrm{pH}$ & $\begin{array}{c}\text { A1 } \\
\text { saturation }\end{array}$ & & $\mathrm{N}$ & $\mathrm{P}$ & $\mathrm{K}$ & $\mathrm{Ca}$ & $\mathrm{Mg}$ & $\mathrm{Mn}$ \\
\hline \multicolumn{2}{|c|}{$\%$} & t/ha & & & $\%$ & & & $p / m$ \\
\hline \multicolumn{9}{|c|}{ Corozal clay } \\
\hline 5.80 & 0 & $26.5 \mathrm{a}^{1}$ & 5.84 & 0.18 & 1.44 & 1.30 & 0.29 & 217 \\
\hline 5.00 & 6 & $25.0 \mathrm{ab}$ & 5.86 & 0.21 & 1.36 & 1.45 & 0.37 & 229 \\
\hline 4.75 & 22 & 26.8 a & 5.84 & 0.18 & 1.43 & 1.39 & 0.35 & 220 \\
\hline 4.50 & 37 & $21.5 \mathrm{ab}$ & 5.92 & 0.22 & 1.36 & 1.39 & 0.38 & 229 \\
\hline 4.40 & 53 & $27.2 \mathrm{a}$ & 5.76 & 0.20 & 1.30 & 1.33 & 0.35 & 247 \\
\hline 4.20 & 70 & $25.6 \mathrm{ab}$ & 5.60 & 0.18 & 1.36 & 1.45 & 0.32 & 321 \\
\hline 4.10 & 82 & $20.0 \mathrm{~b}$ & 6.00 & 0.20 & 1.39 & 1.30 & 0.36 & 270 \\
\hline \multicolumn{9}{|c|}{ Corozal subsoil } \\
\hline 6.00 & 0 & $28.7 \mathrm{a}$ & 5.78 & 0.19 & 1.43 & 1.49 & 0.41 & 173 \\
\hline 5.20 & 4 & $27.0 \mathrm{a}$ & 5.86 & 0.18 & 1.35 & 1.33 & 0.39 & 210 \\
\hline 4.85 & 21 & 25.3 a & 5.78 & 0.17 & 1.34 & 1.49 & 0.37 & 185 \\
\hline 4.65 & 33 & $27.3 \mathrm{a}$ & 5.99 & 0.17 & 1.48 & 1,34 & 0.48 & 180 \\
\hline 4.50 & 48 & $28.6 \mathrm{a}$ & 5.93 & 0.19 & 1.37 & 1.36 & 0.45 & 197 \\
\hline 4.15 & 72 & $19.6 \mathrm{~b}$ & 5.88 & 0.20 & 1.46 & 1.35 & 0.42 & 230 \\
\hline 4.00 & 86 & $17.7 \mathrm{~b}$ & 5.76 & 0.17 & 1.41 & 1.38 & 0.34 & 236 \\
\hline \multicolumn{9}{|c|}{ Coto sandy clay } \\
\hline 5.45 & 0 & $19.4 \mathrm{a}$ & 4.74 & 0.19 & 0.92 & 1.15 & 0.62 & 396 \\
\hline 5.00 & 7 & $21.3 \mathrm{a}$ & 4.57 & 0.17 & 1.09 & 1.16 & 0.58 & 473 \\
\hline 4.80 & 22 & $19.2 \mathrm{a}$ & 4.76 & 0.17 & 0.94 & 1.14 & 0.66 & 468 \\
\hline 4.55 & 36 & $21.3 \mathrm{a}$ & 4.52 & 0.17 & 0.92 & 1.27 & 0.73 & 645 \\
\hline 4.30 & 52 & $19.0 \mathrm{a}$ & 4.59 & 0.17 & 0.98 & 1.17 & 0.58 & 620 \\
\hline
\end{tabular}

${ }^{1}$ Values followed by letters in common do not differ significantly at the $5 \%$ level (Duncan's Multiple Range Test).

experiment was harvested 10 months after planting and yields of fresh roots determined.

\section{RESULTS AND DISCUSSION}

Cassava was very tolerant to high levels of soil acidity (table 1). Yields were significantly depressed only when $\mathrm{pH}$ dropped below about $\mathrm{pH} 4.2$ and $\mathrm{Al}$ saturation was above $70 \%$ in Corozal topsoil and subsoil. Even at 
these extreme levels of soil acidity, cassava produced $73 \%$ of maximum yields in the Corozal soil and $61 \%$ in the subsoil.

Cassava produced somewhat lower yields on the Coto soil and did not respond to soil acidity levels (table 1 ).

Foliar composition was not appreciably affected by soil acidity levels except that $\mathrm{Mn}$ content increased with decreasing $\mathrm{pH}$ and increasing $\mathrm{Al}$

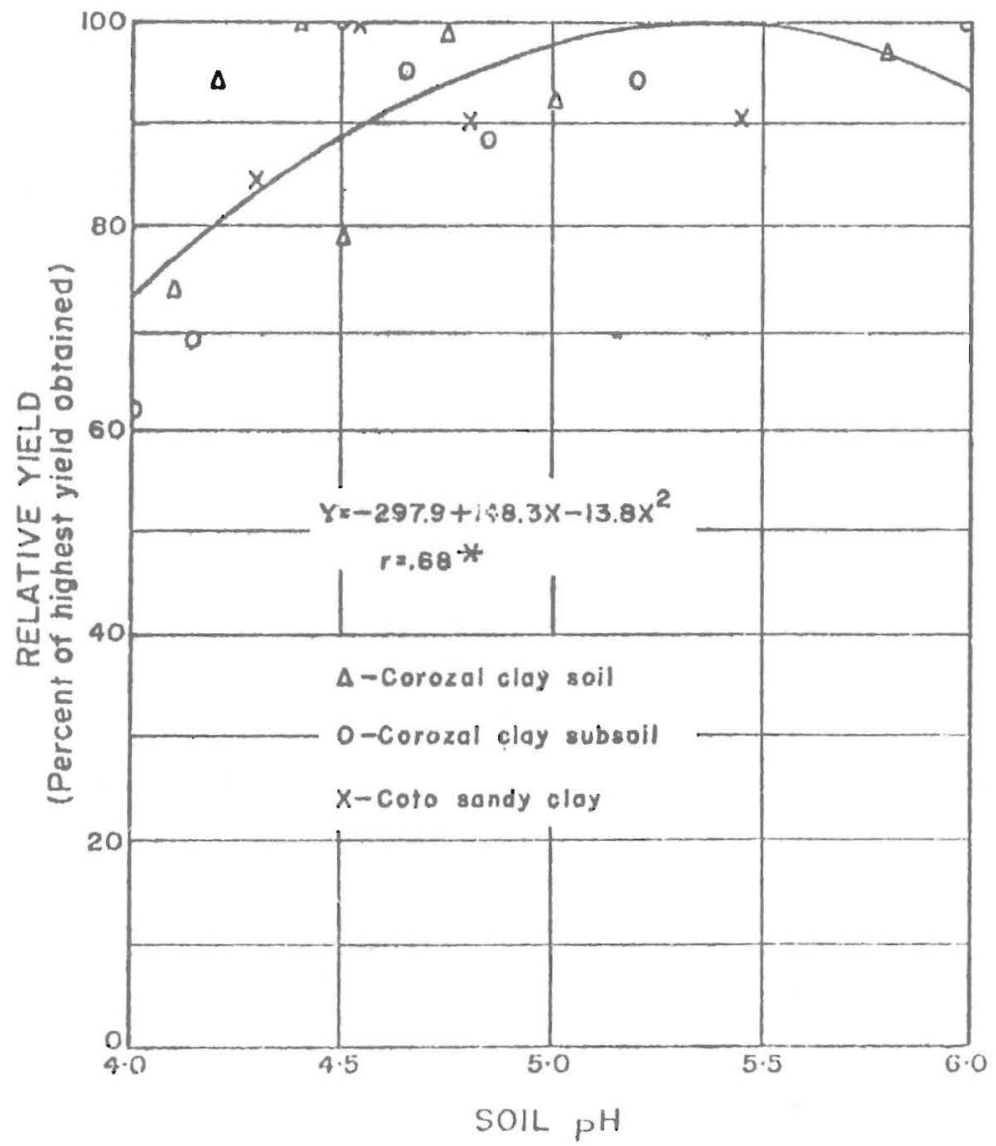

FIG. 1.- Relationship between $\mathrm{pH}$ of two Ultisols and one Oxisol and yields of cassava. Each point represents the mean of at least 3 plots.

saturation, especially in the Coto soil. Leaves of the plants grown in Coto soil had a lower $\mathrm{N}, \mathrm{K}$ and $\mathrm{Ca}$ and a higher $\mathrm{Mg}$ content than those grown in the Corozal soils.

Combined regression analyses of the data for the three soils show that maximum yields were obtained around $\mathrm{pH} 5.5$ (fig. 1) and with $20 \%$ of exchangeable $\mathrm{Al}$ (fig. 2). Around $90 \%$ of maximum yield can be expected 
even at $\mathrm{pH} 4.6$ with $50 \% \mathrm{Al}$ saturation of the soil exchange capacity, an acidity level very common among Ultisols in the tropics. Close to maximum yields of cassava can be expected when the ratio of exchangeable Al to exchangeable bases is around 0.5 (fig. 3).

Table 2 shows that in the experiment to determine the relative tolerance to acidity of 12 cassava varieties, the plots could be grouped into

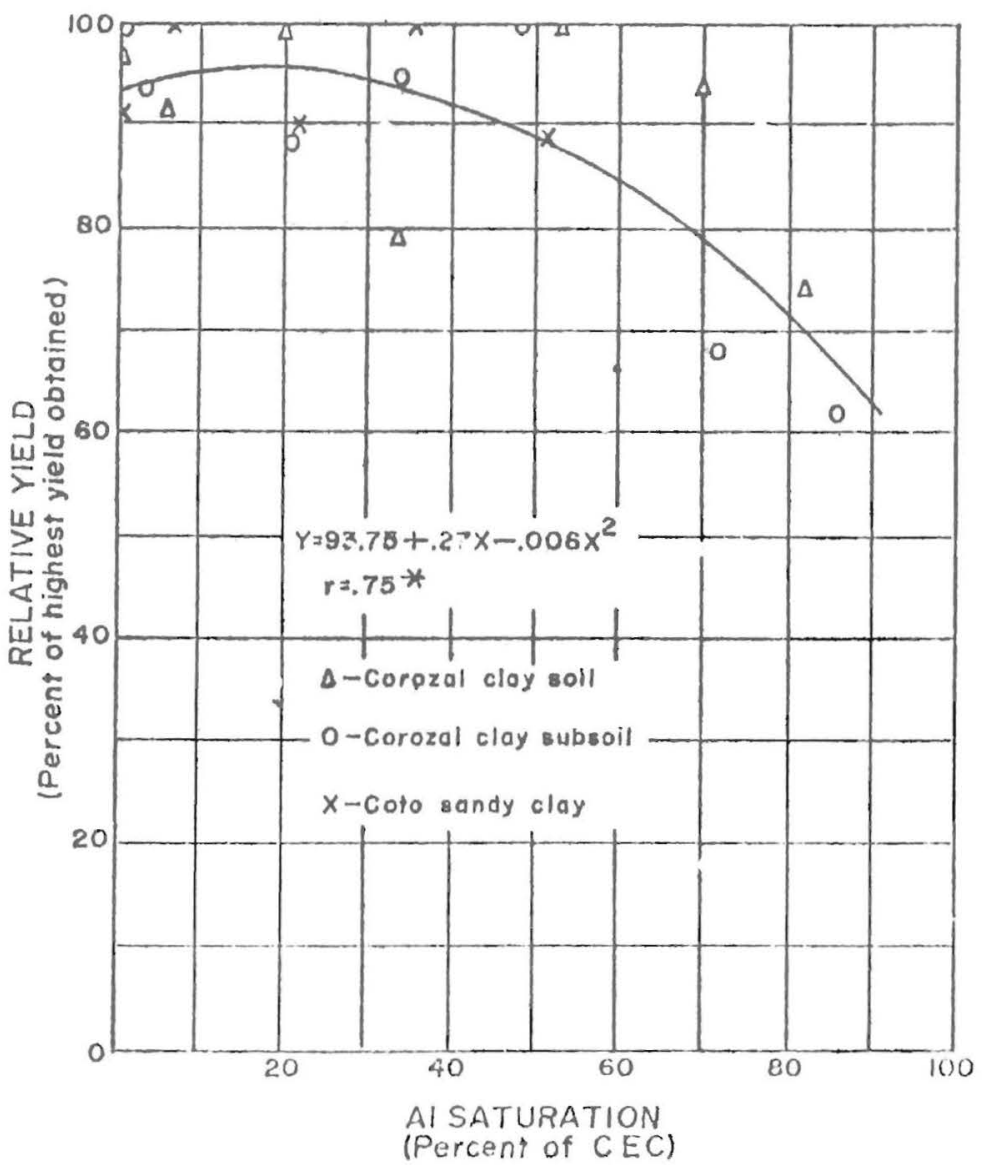

FIG. 2,-Relationship between the exchangeable aluminum content of two Uitisols and one Oxisol and yields of cassava. Each point represents the mean of at least 3 plots.

three levels of acidity. Irrespective of soil acidity, the 12 cassava varieties tested varied widely in yields, from around 17 to $34 \mathrm{~T} /$ ha (table 2), with a general average of $22 \mathrm{~T} / \mathrm{ha}$. The Serrallés variety produced the highest mean yields and cv. PI 12900 the lowest.

Mean yield for the different varieties at each level of soil acidity did not vary appreciably, indicating that the 12 varieties tested had an overall 


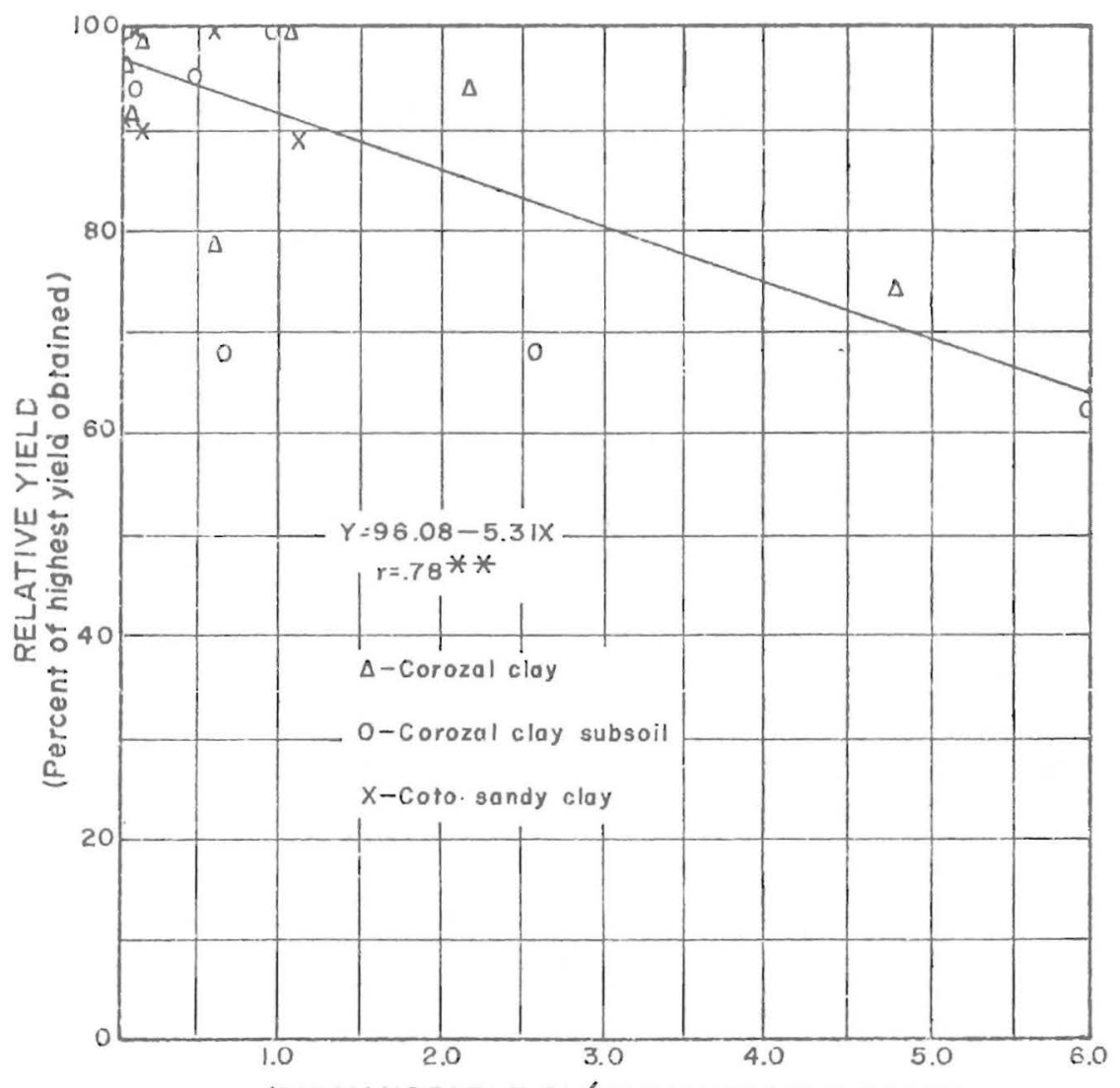

EXCHANGEABLE AI/EXCHANGEABLE BASES

FIG. 3.-Relationship between the ratio of exchangeable aluminum to exchangeable bases of two Ultisols and an Oxisol and the yield of cassava.

high tolerance to high soil acidity. Regression analysis of the data for each variety did not show a correlation between yields of edible roots and soil acidity levels.

\section{RESUMEN}

Experimentos de campo en dos Ultisol y un Oxisol demostraron que la yuca (Manihot esculenta, Crantz) fue altamente tolerante a altos niveles de acidez. La tolerancia fue tal que, a una saturación con $\mathrm{Al}$ del $60 \%$ de la capacidad de cambio catiónico del suelo, se logró un rendimiento equivalente al $85 \%$ del máximo obtenido. Sin embargo, el mayor rendimiento se logró con un pH de 5.3 cuando no había aluminio en el suelo. Los factores de acidez no afectaron la composición química del tejido foliar 
TABLE 2.-The effect of $p H$ and percent AI saturation of the soil on yield of 12 cassava varieties

\begin{tabular}{|c|c|c|c|c|c|c|c|}
\hline Variety & $\begin{array}{l}\mathrm{pH} \\
4.40\end{array}$ & $\begin{array}{c}\% \mathrm{Al} \\
\text { saturation } \\
60\end{array}$ & $\begin{array}{c}\mathrm{pH} \\
4.85\end{array}$ & $\begin{array}{c}\% \mathrm{AI} \\
\text { saturation } \\
20\end{array}$ & $\begin{array}{l}\mathrm{pH} \\
4.75\end{array}$ & $\begin{array}{c}\% \mathrm{Al} \\
\text { saturation } \\
0\end{array}$ & $\begin{array}{c}\text { Average } \\
\text { for } \\
\text { varieties }\end{array}$ \\
\hline & & & & t/ha & & & \\
\hline Serrallés & & 35.3 & & 33.5 & & 33.4 & 34.1 \\
\hline Water Table & & 35.6 & & 25.6 & & 24.3 & 28.5 \\
\hline I.A.C. $12-829$ & & 25.0 & & 34.8 & & 26.5 & 28.8 \\
\hline Llanera & & 26.9 & & 16.2 & & 19.2 & 20.8 \\
\hline Pana & & 29.6 & & 33.1 & & 30.6 & 31.1 \\
\hline Jama 5C & & 20.9 & & 17.3 & & 20.7 & 19.6 \\
\hline Ceiba & & 21.7 & & 25.3 & & 22.5 & 23.3 \\
\hline Forastera & & 21.5 & & 22.6 & & 17.3 & 20.5 \\
\hline Cubana & & 36.6 & & 28.5 & & 18.5 & 27.9 \\
\hline PI 12900 & & 15.2 & & 21.0 & & 14.7 & 17.0 \\
\hline Trinidad 12-56 & & 22.2 & & 22.7 & & 27.3 & 24.0 \\
\hline Trinidad 14-56 & & 28.9 & & 23.1 & & 27.3 & 26.4 \\
\hline Average for treatment & & 26.6 & & 25.3 & & 23.5 & 25.2 \\
\hline
\end{tabular}

de la yuca, excepto el contenido de Mn que aumentó sostenidamente a medida que el pH del Oxisol disminuyó. La alta tolerancia de la yuca a los factores de acidez del suelo quedó plenamente confirmada al no lograrse efecto alguno en el rendimiento de las 12 variedades que se compararon en un Ultisol con concentraciones de $\mathrm{Al}$ cambiable que variaron de $0 \mathrm{a}$ $60 \%$.

\section{LITERATURE CITED}

1. Cheng, K. L. and Bray, R. H. 1951. Determination of calcium and magnesium in soil and plant materials. Soil Sci. 72: 449-58.

2. Edwards, D. G. and Kang, B. T. 1978. Tolerance of cassava (Manihot esculenta Crantz) to high soil acidity. Field Crop Res. 1: 37-46.

3. Howler, R. H., Cadaved, L. F. and Calvo, F. A., 1977. The interaction of lime with minor elements and phosphorus in cassava production. In Symp. of the Int. Soc. for Tropical Root Crops. Cali, Colombia. 1976 International Research Centre, Ottawa, Canada.

4. McLean, E. O. 1965. Aluminum. Methods of soil analysis, Am. Soc. Agron., Agron. Series, 9: 994-96, Madison, Wis.

5. Sithioboosaya, C., Uthayopas, P. and Nakivirijona, C., 1974. Preliminary study on the effect of lime on cassava yields in Thailand. Report on soil field crops-fertilizers. p. 181-184. Thailand Ministry of Agriculture, Bangkok.

6. Spain, J. M., Francis, A., Howler, R. H. and Calvo, F., 1975. Differential species and varietal tolerance to soil acidity in tropical crops and pasture. In Soil Management in Tropical America, Univ. Consortium on Soils of the Tropics, N.C. State University, Raleigh. 